\section{IJ§ER}

ISSN: $2149-5939$

International Journal of Social Sciences and Education Research

Online, http://dergipark.gov.tr/ijsser

Volume: 5(1), 2019

\title{
Forced marriages as human rights violation
}

\author{
Zeynep Reva ${ }^{1}$ and Oğuz Polat ${ }^{2}$
}

Received Date: 10 / 10/2018

Accepted Date: 12 / 01 / 2019

\begin{abstract}
Forced marriage, which is not entered into only with the free and full consent of the intending spouses, is violation of internationally recognised human rights standards. In Turkey; there are many types of forced marriage. Protecting perceived cultural or religious ideals is the most significant factor leads to forced marriage. A forced marriage will be a marriage where all kinds of violence in the family will most likely be experienced. Some European countries made forced marriage into a criminal offence, but it is not defined as a criminal offence in Turkey. This study aims to point out the situation and the types of forced marriages in Turkey and to bring suggestions to struggle with forced marriages.
\end{abstract}

Keywords: Forced marriage, child marriage, early marriage, right to marry, right not to marry, involuntary marriage, human rights violation.

\section{Introduction}

A forced marriage is marriage in which one or both spouses do not give consent to the marriage and violence, threats, or any other form of coercion is involved to actualize the marriage. Coercion may include physical force, the threat of physical force, psychological force, and economical pressure. Forced marriage differs from arranged marriage. In an arranged marriage, parties can refuse to marry if they choose to, but in forced marriage there is no chance to refuse. That is the difference between the forced marriage and the arranged marriage.

Forced marriage is a marriage that takes place without the consent of one or both people in the marriage. Forced marriage may occur when family members or others use physical or emotional abuse, threats, or deception to force someone to marry without his/her consent. Forced marriages is violation of internationally recognised human rights standards. No marriage shall be entered into without the free and full consent of the intending spouses.

This study aims to point out the types and situation of forced marriages, in particular child marriages, in Turkey and to bring suggestions to struggle with forced marriages.

\section{Literature}

Right to marry is an internationally recognised human rights standard as per Article 16 of Universal Declaration of Human Rights, Article 23 of International Covenant on Civil and Po-

\footnotetext{
${ }^{1}$ Attorney-at-Law, LL.M., Ph.D. Candidate. Istanbul Medeniyet University, Medical Law Department Doctorate Program. İstanbul, Turkey, z reva@yahoo.com Contact author. The paper has been presented by this author at the 2nd International Conference on New Approaches in Social Sciences and Humanities dated 26-28 October 2018.

2 Prof. Dr. Acıbadem Mehmet Ali Aydınlar University, Faculty of Medicine, Department of Forensic Medicine. İstanbul, Turkey, ouzpol@yahoo.com
} 
Reva, Z., Polat, O. (2019). Forced marriages as human rights violation. International Journal of Social Sciences and Education Research, 5(1), 69-77

litical Rights, Article of 12 European Convention on Human Rights, Article 16 of the Convention on the Elimination of all Forms of Discrimination against Women (CEDAW), and Article 12 of the Convention on the Rights of the Child (Table-1).

Table 1. Related international standards on right to marry

\begin{tabular}{|c|c|}
\hline $\begin{array}{l}\text { Related international } \\
\text { standard }\end{array}$ & Related article \\
\hline $\begin{array}{l}\text { Universal Declaration } \\
\text { of Human Rights }\end{array}$ & $\begin{array}{l}\text { Article 16: (1) Men and women of full age, without any limitation due to } \\
\text { race, nationality or religion, have the right to marry and to found a family. } \\
\text { They are entitled to equal rights as to marriage, during marriage and at its } \\
\text { dissolution } \\
\text { (2) Marriage shall be entered into only with the free and full consent of } \\
\text { the intending spouses. }\end{array}$ \\
\hline $\begin{array}{l}\text { International Covenant } \\
\text { on Civil and Political } \\
\text { Rights }\end{array}$ & $\begin{array}{l}\text { Article 23: (1) The family is the natural and fundamental group unit of } \\
\text { society and is entitled to protection by society and the State. } \\
\text { (2) The right of men and women of marriageable age to marry and to } \\
\text { found a family shall be recognized. } \\
\text { (3) No marriage shall be entered into without the free and full consent of } \\
\text { the intending spouses. } \\
\text { (4) States Parties to the present Covenant shall take appropriate steps to } \\
\text { ensure equality of rights and responsibilities of spouses as to marriage, } \\
\text { during marriage and at its dissolution. In the case of dissolution, provision } \\
\text { shall be made for the necessary protection of any children. }\end{array}$ \\
\hline $\begin{array}{l}\text { European Convention } \\
\text { on Human Rights }\end{array}$ & $\begin{array}{l}\text { Article } 12 \text { - Right to Marry: Men and women of marriageable age have } \\
\text { the right to marry and to found a family, according to the national laws } \\
\text { governing the exercise of this right. }\end{array}$ \\
\hline $\begin{array}{l}\text { Convention on the } \\
\text { Rights of the Child }\end{array}$ & $\begin{array}{l}\text { Article 12: (1) States Parties shall assure to the child who is capable of } \\
\text { forming his or her own views the right to express those views freely in all } \\
\text { matters affecting the child, the views of the child being given due weight } \\
\text { in accordance with the age and maturity of the child. } \\
\text { (2) For this purpose, the child shall in particular be provided the oppor- } \\
\text { tunity to be heard in any judicial and administrative proceedings affecting } \\
\text { the child, either directly, or through a representative or an appropriate } \\
\text { body, in a manner consistent with the procedural rules of national law. }\end{array}$ \\
\hline $\begin{array}{l}\text { The Convention on the } \\
\text { Elimination of all Forms } \\
\text { of Discrimination } \\
\text { against Wom- } \\
\text { en(CEDAW) }\end{array}$ & 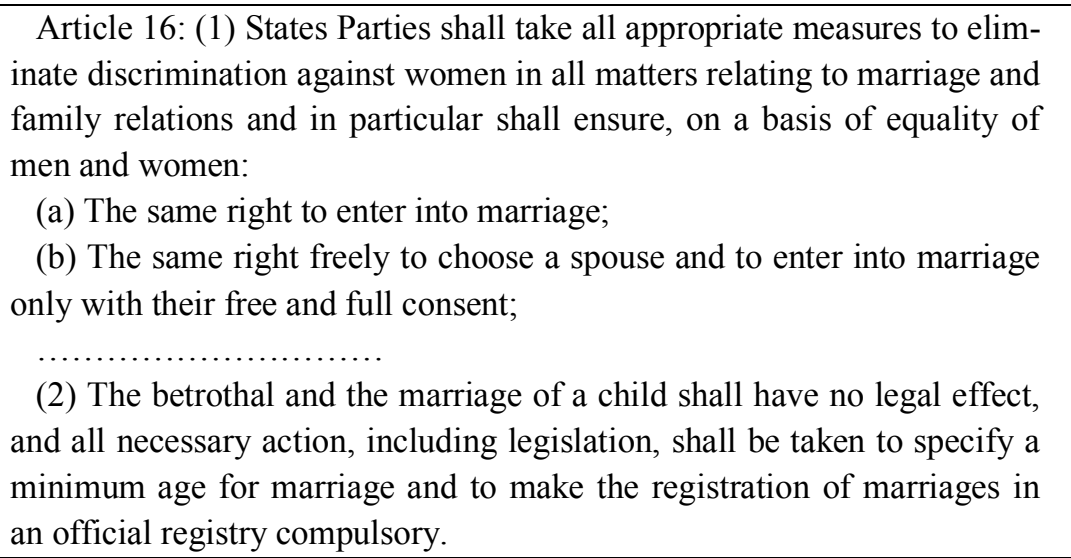 \\
\hline
\end{tabular}

When it is investigated the national legislation of Turkey, Article 41 of the Constitution of The Republic of Turkey and Article 124 of Turkish Civil Code may be indicated as the significant legislation. It is stated that the family is the foundation of the Turkish society and based on 
Reva, Z., Polat, O. (2019). Forced marriages as human rights violation. International Journal of Social Sciences and Education Research, 5(1), 69-77.

the equality between the spouses in Article 41 of the Constitution of the Republic. According to Article 124 of Turkish Civil Code, male or female may not get married unless completing full age of seventeen.

\section{Methodology}

This study is a systematic review of forced marriages and that were conducted in Turkey to discuss the issue with a wider perspective. This conceptual paper is based on a systematic review and analysis of research and data from the literature, and the statistics of UNICEF, World Bank, Turkish Statistical Institute, and Ministry of Justice. The method of this study is literature and statistics screening method. The literature review was carried out in "Acibadem University Database", "Ulakbim Turkish Academic Network and Information Center", "Google Scholar". The research was made between June 2018 and October 2018 and 5 keywords were used: "forced marriage", "child marriage", "early marriage", "right to marry", and "involuntary marriage".

\section{Findings}

\subsection{Victims of forced marriages}

Forced marriage is a problem to be encountered all over the world, not a problem specific to one country or culture. Since it was established in 2005, the Foreign and Commonwealth Office has handled cases relating to over 90 countries across Asia, the Middle East, Africa, Europe and North America (Foreign and Commonwealth Office, 2018).

When it is looked from gender perspective; women are faced to this problem more than men. According to a report, in 2017, the majority of cases 930 (77.8\%) involved women; 256 cases (21.4\%) involved males. These proportions are in line with previous years. When it is looked from age perspective; children and young persons are faced to this problem more than older persons. According to the report, of the cases, that Foreign and Commonwealth Office provided support to; 355 cases (29.7\%) involved victims below 18 years of age; and 353 cases (29.5\%) involved victims aged 18-25 (Foreign and Commonwealth Office, 2018).

\subsection{Types of forced marriages in Turkey}

In Turkey; there are many types of forced marriage, such as Taygeldi marriage, marriage with brother-in-law (Levirat), marriage with sister-in-law (Sorarat), blood money marriage, marriage against bride wealth, berder (berdel) marriage, abduction, co-wife marriage, marriage for revenge, and child marriage (Balaman, 2002: 42-45)

a) Taygeldi marriage: It is known also as "with mother and daughter" or "with inside and outside" Marriage of two widows having children from different genders in company with the marriage of children of them (Balaman, 2002: 42-45; Yasa, 1962: 300-305). It is not observed in west. It is specific to Islamic countries. In the event that both widows have children in marriage age or in early age from different genders and in equal number, then the real or symbolic marriage of widows and children is called as taygeldi marriage.

b) Marriage with brother-in-law (Levirat): It refers the marriage of brother of a deceased elder brother with the wife of his elder brother. It is frequently seen in Eastern and South-eastern Anatolia. The customary power that is compulsory to comply in Eastern Anatolia and South-eastern Anatolia makes pressure in direction to get married with the younger brother but absolutely not 
Reva, Z., Polat, O. (2019). Forced marriages as human rights violation. International Journal of Social Sciences and Education Research, 5(1), 69-77

the elder brother of the deceased person. The elder brother is deemed as the elder brother of the bride so it is deemed that they are not eligible to get married with each other. This kind of marriage is not much encountered in our western regions.

The law referred it as "Atypical form of marriage"; if the brother is married, it is colloquially referred as "co-wife" or "with inside and outside with partner". Only religious marriage is solemnized and the born child is registered in the civil registry of the first wife (Yasa, 1962: 300-305; Poyraz Tacoğlu, 201: 114-116).

This marriage is realized with the choice of the family not the choice of the individuals to get married with. The purpose is to preserve the integrity of the family and to prevent the children to be abandoned and suppressed. The married woman has joined to that family and must not leave it anymore.

c) Marriage with sister-in-law (Sorarat): It is a special cultural tradition. The marriage of widow man with the sister of his ex-wife. It is tried to be rationalized with the consideration that the aunt selected as stepmother will be more tolerant to the orphaned children (Balaman, 2002: 4245).

d) Blood Money: It is a kind of marriage where daughters are granted in company with materials assets against blood money to the families that have blood feud between them. It is formed by the custom as it is the case in levirat. It is encountered more frequently in regions of Eastern and South-eastern Anatolia like other enforced marriages. (Balaman, 2002: 42-45). There is not there any consent of the marrying individuals. Marrying against blood money is a primitive form of marriage based on lack of education. The only positive aspect of such marriages is the fact that they terminate blood feuds (Sezen, 2005: 185-195).

e) Marriage with Bride wealth: Bride wealth refers to the money paid by the young man to get married to the family of the girl. It can be granted in gold, house, garden, field and animal as well as it can be paid in cash money. It is commonly performed in rural parts of the Regions of Eastern and South-eastern Anatolia (Balaman, 2002: 42-45).

f) Berder (berdel) Marriage: It is known as "Kepir" in Hakkari, "Performing Exchange" in Denizli-Aydın and "Berdel" in Eastern and South-eastern Anatolia. It is the exchange of sisters by two men in marriage age from one to the other. Generally it is performed because of being able to pay bride wealth (for poor families) or in order to further reinforce the relations like sheikhdom and landlord status for ones who are from higher socioeconomic level. It is done with the purpose to ensure the efficiency in family and the control over children (Balaman, 2002: 42-45).

a) Abduction: Abduction is committed in events that families object a marriage. Claiming bride wealth is also a factor in this (Balaman, 2002: 42-45).

b) Marriage with co-wife: The man whose wife is infertile or cannot deliver a son is made to marry again and then the man lives with multiple women usually in same home. It is commonly performed in the Regions of Eastern and South-eastern Anatolia (Balaman, 2002: 42-45).

c) Marriage for Revenge: Some families having blood feud between them use this means in order to tarnish the opposite family's honour and to damage their reputation (Balaman, 2002: 42 45).

d) Betrothed in the cradle: Friends, fellows, neighbours or relatives who love each other very much perform engagement of their children when they are in cradle by tying notching (mark, cloth) to cradle and thus promise that their babies will marry each other (Balaman, 2002: 42-45).

e) Child Marriage: Child marriage is defined as a marriage or union taking place before the age of 18 . 
Reva, Z., Polat, O. (2019). Forced marriages as human rights violation. International Journal of Social Sciences and Education Research, 5(1), 69-77.

\subsection{Child marriage}

\subsubsection{In generally}

Child marriage is a problem that prevents the exercise of human rights, undermines the status of women and deprive child from their fundamental rights. Child marriages can be faced in every region all over the world, from the Sub-Saharan to Latin America, Middle East to Europe.

Children (especially girls) and young persons (especially young women) are faced to this problem more than older persons. In many countries, a large share of girls still marry before the age of 18 . The international community and country governments are increasingly aware of the negative impacts of child marriage, yet investments to end the practice remain limited. Worldwide, more than 700 million women alive today (18,6\% of the female population in the world) were married before their 18th birthday. More than one in three (about 250 million) entered into union before age 15 (World Bank, 2014).

Child marriage also affects boys, but to a lesser degree than girls (Unicef, 2018). Many factors interact to place a girl at risk of marriage, including poverty, the perception that marriage will provide 'protection', family honour, social norms, customary or religious laws that condone the practice, an inadequate legislative framework and the state of a country's civil registration system. Child marriage often compromises a girl's development by resulting in early pregnancy and social isolation, interrupting her schooling, limiting her opportunities for career and vocational advancement and placing her at increased risk of domestic violence (UNICEF, 2018).

Child marriage is fuelled by gender inequality, poverty, traditions, and insecurity. But drivers will vary from one community to the next and the practice may look different across regions and countries, even within the same country (Girls not Brides, 2018).

According to the UNICEF database, Niger has the highest rates of child marriage in the World with $76 \%$ of the girls getting married before the age of 18 . Turkey has one of the highest rates of child marriage in Europe with an estimated 15\% of the girls getting married before the age of 18 (UNICEF Database; UNICEF 2018) (Table-2). However, statistical data available may not be representative of the scale of the issue since some of the child marriages are unregistered and take place as unofficial religious marriages.

Table 2. Related international standards on right to marry

\begin{tabular}{|c|l|c|c|c|}
\hline Rank & \multicolumn{1}{|c|}{ Country } & Married by 15 & Married by 18 & Source \\
\hline 1 & Niger & 28 & 76 & DHS 2012 \\
\hline 2 & Central African Republic & 29 & 68 & MICS 2010 \\
\hline 3 & Chad & 30 & 67 & DHS 2014-15 \\
\hline 4 & Bangladesh & 22 & 59 & DHS 2014 \\
\hline 5 & Burkina Faso & 10 & 52 & DHS 2010 \\
\hline 6 & Mali & 17 & 52 & MICS 2015 \\
\hline 7 & South Sudan & 9 & 52 & SHHS 2010 \\
\hline 8 & Guinea & 19 & 51 & MICS 2016 \\
\hline 9 & Mozambique & 14 & 48 & DHS 2011 \\
\hline 10 & Somalia & 8 & 45 & MICS 2006 \\
\hline 87 & Turkey & 1 & 15 & DHS 2013 \\
\hline
\end{tabular}

Source: UNICEF Database, last updated March 2018 
Reva, Z., Polat, O. (2019). Forced marriages as human rights violation. International Journal of Social Sciences and Education Research, 5(1), 69-77

\subsubsection{In Turkey}

Under Article 124 of Turkish Civil Code; the minimum legal age of marriage is; 18 without parental consent; 17 with parental consent; and 16 with court authorization.

Mean age at first marriage was 27.7 for males and 24.6 for females in 2017. According to the marriage statistics of TURKSTAT, while the proportion of legal child marriages for girls aged between 16 and 17 within the total legal marriages were $6.2 \%$ in 2013 , it declined to $4.2 \%$ in 2017. In province-based analyses in 2017 , the province with the highest proportion of child marriages for girls was Ağr1 with the proportion of $16.6 \%$. This province was followed by Muş with $16.1 \%$ and Bitlis with $12.3 \%$. The three provinces with the lowest proportion of child marriages for girls within total marriages were Tunceli with $0.4 \%$, Rize with $1.1 \%$ and Trabzon with $1.4 \%$ respectively (TURKSTAT, March 2018; TURKSTAT, April 2018) (Table-3).

Table 3. Provinced based child marriages

\begin{tabular}{|c|c|c|c|c|}
\hline Rank & Province & $\begin{array}{c}\text { Total Number of } \\
\text { Marriage }\end{array}$ & $\begin{array}{c}\text { Number of Girl } \\
\text { Child Marriage }\end{array}$ & $\begin{array}{c}\text { Proportion of Girl Child } \\
\text { Marriage in Total Marriage }\end{array}$ \\
\hline 1 & Ağrı & 4,300 & 712 & 16,6 \\
\hline 2 & Muş & 3,204 & 517 & 16,1 \\
\hline 3 & Bitlis & 2,568 & 315 & 12,3 \\
\hline 4 & Niğde & 2,683 & 328 & 12,2 \\
\hline 5 & Ardahan & 621 & 74 & 11,9 \\
\hline 6 & Kars & 1,880 & 223 & 11,9 \\
\hline 7 & Kilis & 1,282 & 148 & 11,5 \\
\hline 8 & Van & 8,779 & 947 & 10,8 \\
\hline 9 & Gaziantep & 15,191 & 1,591 & 10,5 \\
\hline 10 & Kahramanmaraş & 8,092 & 801 & 9,9 \\
\hline--- & --- & --- & --- & 1,4 \\
\hline 79 & Trabzon & 5,120 & 73 & 1,1 \\
\hline 80 & Rize & 2,021 & 22 & 0,4 \\
\hline 81 & Tunceli & 445 & 2 & 4,2 \\
\hline & Toplam-Total & 569,459 & 23,906 & \\
\hline
\end{tabular}

Source: Turkstat, Statistics on Child, 2017

The provinces with the highest rates are located in Eastern and South-eastern Anatolia in Turkey. Child marriage statistics are officially published for children 16-17, but data on child marriage before the age of 16 is not available.

In 2017; the total number of all marriages is 569.459 , and 23.906 of those is girl child marriage (TURKSTAT, March 2018). Child marriage statistics are officially published for children 16-17, but data on child marriage before the age of 16 is not available.

According to the data of 2017 of the Ministry of Justice (Statistics of Ministry of Justice, 2017); the number of lawsuits in subject of permission for marriage filed in Family Courts is 8,581, and of the cases, 7384 were fully or partially accepted; and The province with the highest rate of these lawsuits is located in Southeast Anatolia in Turkey. This data reveals only that the number of girls married officially in minor age is high. 
Reva, Z., Polat, O. (2019). Forced marriages as human rights violation. International Journal of Social Sciences and Education Research, 5(1), 69-77.

\section{Results}

Forced marriage is marriage in which one or both spouses do not give consent to the marriage. It can be encountered all over the world. Forced marriages are commonly encountered in rural parts of Turkey, in particular at the regions of Eastern and South-Eastern Anatolia. In Turkey; there are many types of forced marriage, such as taygeldi marriage, marriage with brotherin-law (levirat), marriage with sister-in-law (sorarat), blood money marriage, marriage against bride wealth, berder (berdel) marriage, abduction, co-wife marriage, marriage for revenge, and child marriage. Child marriage may be specified the most significant one of the forced marriages types. Turkey has one of the highest rates of child marriage in Europe with an estimated 15\% of the girls getting married before the age of 18. Although there is no official data regarding forced marriages (except child marriages), naming the kinds of it implies that it is quite common.

The main factors leads to forced marriage, in particular child marriages, may be specified as lack of education, custom and tribe factor, control of women's free behaviour, family honour, misinterpretation of religious knowledge, domestic violence, social and family pressure on parents economic reasons, migration, and exposure to abuse and rape (KADEM, 2014). Additionally, protecting perceived cultural or religious ideals is the most significant factor of the forced marriages. Despite the changing socio-cultural structures especially in eastern and south eastern regions; customs and tribal traditions preserve their significance in some regions where traditional and cultural effects, habits and pattern judgments dominate. Customs that we can define as unwritten social rules is a concept that allows early marriages. Existence of a great number of proverb justifying marriage in childhood age in Turkish reveals the effect of the factor of custom: "girl is in cradle and dowry is in coffer", "Girl in fifteen is either with husband or on ground", "Iron in temper, belle in age", "Whoever get married early takes child, whoever get up early makes way" "Whoever got married early has not been mistaken" and so on.

A forced marriage will be a marriage where all kinds of violence in the family - physical, emotional, economic and sexual - will most likely be experienced. The serious impacts, especially for young women, can be vary and widely. In addition to emotional and sexual influences such as living and sleeping with an undesirable person, there are some more other consequences such as lack of right of education and work, economic dependence on man/husband, chronic psychosomatic diseases and even suicidal drag.

Forced marriage is considered as a criminal offence in some European countries such as Belgium, Norway and Germany, but not in Turkey (Parrot and Cummings, 2008, 33; Atun and Atun, 2018, 571-579). On the other hand, there is a difference in terms of being in sexual intercourse with the child (indirectly for child marriages). According to the Turkish Penal Code it is considered as a criminal offence to be in sexual intercourse with minors under 15 either even if the consent of minor exists.

\section{Conclusion}

Forced marriages are commonly encountered in rural parts of Turkey, in particular at the regions of Eastern and South-Eastern Anatolia. It is aimed to emphasize the forced marriages as one of the big problems of Turkey, so that there are many types of forced marriages in Turkey. Although there is no official data regarding forced marriages (except child marriages), naming the kinds of it implies that it is quite common. 
Reva, Z., Polat, O. (2019). Forced marriages as human rights violation. International Journal of Social Sciences and Education Research, 5(1), 69-77

An individual's right to choose a spouse and enter freely into marriage is central to his/her life and dignity, and equality as a human being. It is important to educate individuals and society about the right to marry and not to marry, the natural extension of the most basic human rights of marriage, the terrible impacts of the forced marriage on the young women and children, and to address the issue of bringing legal regulations that will prevent forced marriages such as defining the forced marriage as a criminal offense. To struggle with forced marriages, in particular child marriages; it is necessary to hold meetings, trainings and workshops to create and develop awareness for implementation of relevant provisions of Turkish Civil Code, Turkish Penal Code and Law on Protection of Minors and raise awareness on the impact of the forced marriages. It is also important to address the issue of bringing legal regulations that will prevent forced marriages such as defining the forced marriage as a criminal offense.

\section{References}

Atun, Y. \& Atun, A. (2018). The unfounded mass burials of the so-called Armenian Genocide. International. Journal of Social Sciences and Education Research, 4(4), 571-579. http://dergipark.gov.tr/download/article-file/552789 (Last accessed on 23.12.2018)

Balaman, A.R. (2002). Marriage Kinship Types. Publications of Ministry of Culture of Turkish Republic, Ankara, 42-45,

Constitution of The Republic of Turkey: http://www.constitutionalcourt.gov.tr/inlinepages/ legislation/pdf/constitution_en.pdf (Last assessed on 23.12.2018)

Forced Marriage Unit Statistics (2017). Foreign and Commonwealth Office, 16 March 2018. https://assets.publishing.service.gov.uk/government/uploads/system/uploads/attachment_data/file/730 155/2017_FMU_statistics_FINAL.pdf

KADEM (2014). Workshop Report on Fight against Early Marriages and Forced Marriages in Turkey, http://kadem.org.tr/erken-yasta-ve-zorla-evliliklere-karsi-mucadele-calistay-raporu/ (Last assessed on 23.12.2018)

Parrot, A. \& Cummings, N. (2008), Sexual Enslavement of Girls and Women. Worldwide, Westport, CT. Lobdon, Praeger.

Poyraz Tacoğlu, T. (2011). The Reasons for Traditional Marriages in Turkey and the Effects of Custom on Marriages. METU Institute of Social Sciences Journal of Social Sciences Research. ISSN: 13099302. Volume: 2 Issue: December 4, 2011: 114-143.

Sezen, L. (2005). Marriage Types in Turkey. Atatürk University Turkish Intermediate Research Institute Journal, Issue: 27, Prof. Dr. Sinasi Tekin Special Issue, 2005: 185-195.

Statistics of Ministry of Justice, 2017. http://www.adlisicil.adalet.gov.tr/istatistik_2017/ istatistik2017.pdf (Last accessed on 22.08.2018).

Turkish Civil Code: http://www.mevzuat.gov.tr/MevzuatMetin/1.5.4721.doc (Last assessed on 23.12.2018)

TURKSTAT (April 2018) Statistics on Children, 2017, No: 27596, 18 April 2018

TURKSTAT (March 2018). Marriage and Divorce Statistics, 2017, No: 27593, 02 March 2018.

UNICEF Database. https://data.unicef.org/wp-content/uploads/2015/12/Child-marriage-database_Mar2018.xlsx (Last accessed on 23.12.2018)

UNICEF (2018), Progress for Every Child in the SDG Era, March 2018.

World Bank, Economic Impacts of Child Marrage: (Conference Edition) June 2017, Global Synthesis Unicef, Ending Child Marriage, Progress and Prospects, 2014. 
Reva, Z., Polat, O. (2019). Forced marriages as human rights violation. International Journal of Social Sciences and Education Research, 5(1), 69-77.

Yasa, İ. (1962). Taygeldi Family. Ankara University Faculty of Political Science Journal, Ankara, Volume: $17: 300-305$

https://data.unicef.org/topic/ child-protection/child-marriage/ (Last assessed on 23.12.2018)

- https://www.girlsnotbrides.org/why-does-it-happen/ (Last assessed on 23.12.2018) 